\title{
Characterization and evaluation of Flammulina mexicana growth in lignocellulosic residues
}

\author{
Caracterización y evaluación del crecimiento de Flammulina mexicana \\ en residuos lignocelulósicos
}

\author{
Yolanda Arana-Gabriel a, Cristina Burrola-Aguilar a*, Sergio Franco-Maass ${ }^{\text {b, }}$ \\ Gerardo Mata ${ }^{\text {c }}$, Carmen Zepeda-Gómez ${ }^{\text {a }}$ \\ *Corresponding author: a Universidad Autónoma del Estado de México, Facultad de Ciencias, \\ Centro de Investigación en Recursos Bióticos, km 14.5, carretera Toluca-Atlacomulco, C.P. 50200, Toluca, \\ Estado de México, México, tel.: +52 (722) 29655 53, cba@uaemex.mx \\ ${ }^{\mathrm{b}}$ Universidad Autónoma del Estado de México, Instituto de Ciencias Agropecuarias y Rurales, \\ El Cerrillo Piedras Blancas, Toluca, Estado de México, México.

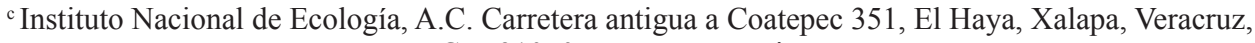 \\ C.P. 91070 , Veracruz, México.
}

\begin{abstract}
SUMMARY
Flammulina mexicana is a fungus species endemic to high mountains and has potential for commercial cultivation. Four strains were isolated from wild fruit bodies and its growth was evaluated in two culture media. There were no morphological differences among these strains; however, the choice of culture media did produce differences. Growth rate was superior in strains IE 974 and IE 986 at $0.65 \mathrm{~cm}_{\text {day }}{ }^{-1}$. These strains also presented the highest biomass production at 6.9 and $7.7 \mathrm{~g} \mathrm{~L}^{-1}$, respectively; with a period of 35 days in production with solid spawn and 20 days with liquid spawn. All the four strains have the ability to fructify in agricultural and forestry wastes. Strains IE 986 and IE 974 presented better biological efficiency at $34.5 \%$ and $31.9 \%$, respectively, with maize stubble as a substrate. A nutritional analysis of the fructifications obtained showed a high percentage of fiber $(52.51 \%)$ and low carbohydrate content $(9.03 \%)$. For this reason, culture of these species represents an alternative for their ex situ conservation and use.
\end{abstract}

Key words: native strains, liquid spawn, maize stubble, fruit bodies, hemicellulose.

\section{RESUMEN}

Flammulina mexicana es una especie fúngica endémica de alta montaña con potencial para ser cultivada. A partir de esporomas silvestres, se aislaron cuatro cepas y se evaluó su crecimiento en dos medios de cultivo. No se presentaron diferencias morfológicas entre cepas, pero sí entre medios de cultivo. La velocidad de crecimiento fue mayor en las cepas IE 974 y IE $986 \mathrm{con} 0,65 \mathrm{~cm} /$ día y la mayor producción de biomasa con 6,9 y $7,7 \mathrm{~g} / \mathrm{L}$, respectivamente; con un tiempo de 35 días para la producción de inóculo sólido y 20 para inóculo líquido. Las cuatro cepas tienen capacidad de fructificar en desechos agrícolas y forestales. Las cepas IE 986 e IE 974 presentaron mayor eficiencia biológica con 34,5\% y 31,9\%, respectivamente, en rastrojo de maíz como sustrato. El análisis nutricional de las fructificaciones obtenidas muestra un alto porcentaje de fibra $(52,51 \%)$ y bajo contenido de carbohidratos $(9,03 \%)$. Por lo que, el cultivo de esta especie representa una alternativa para su conservación ex situ y su aprovechamiento.

Palabras clave: cepas nativas, inóculo líquido, rastrojo de maíz, cuerpo fructífero, hemicelulosa.

\section{INTRODUCTION}

In Mexico, 371 species of wild mushrooms are consumed (Garibay-Orijel and Ruan-Soto 2014); however, not more than five of these species are cultivated at commercial scale and experimentation with new cultures is relatively recent and rare (Garibay-Orijel et al. 2010). Wild mushrooms represent a very important biological and genetic resource that offers great potential for the cultivated mushroom productive sector. They are organisms that develop in given substrates and environmental conditions; which provide the genetic variation necessary to produce the characteristics desired by the commercial sector. Given their importance to the ecosystem and high economic potential, exploitation of wild mushrooms requires sustainable management to guarantee conservation of the wild germplasm (Salmones and Mata 2012).

Cultivation of new species of wild mushrooms represents a strong potential for the preservation of traditional knowledge and acquisition of new genes and functional 
properties (Morales et al. 2010). Cultivation of species valued by regional populations helps to promote their consumption and commercialization, ensuring the commercial viability of new businesses. These mushroom cultures can be an alternative for the reduction of contamination caused by organic agricultural, forestry or agro-industrial wastes, converting them into nutritious foods (Royse 1996, Philippoussis et al. 2001) and contributing to solving problems such as food insufficiency. One example of this is mushroom Flammulina mexica$n a$ Redhead, Estrada et R.H. Petersen, commonly known as "hongo de jara", whose consumption has been documented in five locations from Nevado de Toluca, Mexico and mentioned within the 20 species of mushrooms of higher cultural importance according to the traditional knowledge generated from research carried out in the area (Franco-Maass et al. 2012). In addition, it has already been tested in an in vitro culture from a wild strain (Arana-Gabriel et al. 2014). This species is endemic to the high mountains (Redhead et al. 2000), grows at elevations above $2,700 \mathrm{~m}$, at temperatures below $18{ }^{\circ} \mathrm{C}$ (Redhead et al. 2000, Franco et al. 2012, Arana-Gabriel et al. 2014). Flammulina mexicana presents sexual reproduction of the bifactorial heterothallic type (Redhead et al. 2000) and saprotrophic habit, fructifying on Senecio cinerarioides A. Rich., a shrub that grows in high mountain forests and commonly known as "jara". In general, the genus Flammulina is considered cosmopolitan in deciduous forests and tolerant to low temperatures, for these reasons it is recognized as a winter mushroom. Flammulina velutipes (Curtis) Singer is the best-known species of the genus, it is one of the most cultivated mushrooms of the world due to its nutritional value and its therapeutic use (Sharma et al. 2010, Royse et al. 2017).

For Flammulina mexicana, the environmental conditions and the substrates required for the formation of fruiting bodies had not been previously described. Therefore, in this research it was necessary to use strains of different fruit bodies, to contribute to genetic selection, and thereby identify germplasm with desirable characteristics for the commercial sector (Savoie and Mata 2016). This genetic variety of the strains is expressed in variables such as growth rate, biomass production, fruit body production and biological efficiency. The characterization and evaluation of these variables help to have better strains, this is because not all of them have the capacity to form fruiting bodies, in addition to the fact that the growth rate and the biomass of the strains are not necessarily reflected in the biological efficiency (De León et al. 2012, León-Avendaño et al. 2013, Saboya and Mata 2016).

Due to this problem, the objective of the present investigation is to compare the biological efficiency of wild strains of $F$. mexicana on various lignocellulosic residues under controlled conditions at the laboratory level.

Because the nutritional and environmental conditions of the F. mexicana strains modify their growth rate and the production of fruiting bodies, as an expression of the genetic variety, it is expected that the strains with a higher growth rate and production of biomass on in vitro culture will present superior biological efficiency and short culture cycles.

\section{METHODS}

Collection and characterization of fruit bodies. Fruit bodies were collected from a sample directed to different secondary vegetation sites of Senecio cinerarioides from Nevado de Toluca Flora and Fauna Protection Area in Mexico. The specimens collected were characterized based on Delgado et al. (2005) and were identified according to Redhead et al. (2000) and Franco et al. (2012). Voucher specimens were deposited in the fungal collection of the National Herbarium of Mexico, at the Biology Institute of the UNAM (MEXU), under the following registry numbers: 27411, 28146, 28150, 28151.

Acquisition and morphological characterization of strains. Strains of F. mexicana were obtained from mushrooms collected on both dead material and live branches in different shrubs of $S$. cinerarioides by vegetative isolation in a dog food agar (DFA) medium and subsequent incubation at $18{ }^{\circ} \mathrm{C}$ in darkness. Tissue fragments were submerged in oxygenated water for 30 minutes and washed with sterile distilled water to avoid contamination. The strains obtained were deposited in the strain collection of the Ecology Institute (INECOL) in Xalapa, Veracruz, Mexico, with the keys: IE 984, IE 985, IE 986 and evaluated together with the strain IE 974 of F. mexicana obtained in a previous study (Arana-Gabriel et al. 2014). The sequences of each strain were also deposited in GenBank under the accession numbers: KY794659, KY794660, KY794661 and KY794662, respectively.

Once the mycelium had completely invaded the Petri dish, macroscopic characterization was conducted, based on Cruz-Ulloa (1995) and using the color key HTML Color Codes (2017). For the microscopic characterization, temporary preparations were made with $10 \%$ Congo Red to verify the presence of clamps connections. The diameter of the hyphae was measured at 100x (20 hyphae per treatment) using the program Motic digital Microscope DMB3-223 (Motic China Group Co., Ltd., 2001-2004).

Growth rate of strains in a solid medium. With a borer, 5 $\mathrm{mm}$ diameter samples were removed from the agar containing mycelium and placed in the center of Petri dishes ( 9 $\mathrm{cm}$ in diameter) in two culture media. One non-conventional medium: DFA (15 $\mathrm{g}$ of agar, $15 \mathrm{~g}$ of dog croquettes of the brand GANADOR ${ }^{\circledR}, 2 \mathrm{~g}$ of yeast extract, $1 \mathrm{~g}$ of gelatin peptone in one liter of distilled water) (Stamets 2000, Arana-Gabriel et al. 2014) and one conventional medium: malt extract agar with added peptone and yeast (MEA-PY) (31.9 $\mathrm{g}$ of malt extract agar, $2 \mathrm{~g}$ of yeast extract, $1 \mathrm{~g}$ of ge- 
latin peptone in one liter of distilled water). Five replicates were conducted per treatment and strain. The strains were incubated in darkness at $18{ }^{\circ} \mathrm{C}$. Strain diameter was measured every third day with a Vernier (metal vernier caliper 5 " Pretul ${ }^{\circledR}$, ver-6p, China). The growth rate (GR) was obtained using the equation of Huerta et al. (2009) GR=(FdId)/(Ft-It) (where "Fd" is the final diameter of growth, "Id" is the initial diameter of growth and "Ft-It" is the duration of the period of mycelial growth in days).

Biomass production of strains in a solid medium. Once the incubation period of the strains was over, the agar of the samples was eliminated by immersion in boiling water. The mycelium was recovered, filtered and rinsed with hot water. It was then oven-dried at $80{ }^{\circ} \mathrm{C}$ for 24 hours and weighed to obtain the dry biomass (Arana-Gabriel et al. 2014). Five replicates were conducted per treatment and strain.

Biomass production of strains in a liquid medium. One hundred $\mathrm{ml}$ of the dog food medium with peptone and yeast (DF-PY) and malt extract with peptone and yeast (ME-PY) were placed in $250 \mathrm{ml}$ Erlenmeyer flasks (five replicates per treatment). All the culture media of the different treatments were sterilized in an autoclave at $121{ }^{\circ} \mathrm{C}$, $15 \mathrm{lb}$ psi for 15 minutes and $0.05 \mathrm{~g}$ of Chloramphenicol (SIGMA ${ }^{\circledR}$ ) added as an antibiotic. The media inoculated with $0.5 \mathrm{~cm}$ in diameter of mycelium were incubated for 20 days at $18{ }^{\circ} \mathrm{C}$ and at $120 \mathrm{rpm}$ in a water bath with agitation (PolyScience $\left.{ }^{\circledR}\right)$. Five replicates were conducted per treatment and strain. At the end of this incubation period, the $\mathrm{pH}$ of the medium was measured, and the mycelium filtered and left to dry at $80^{\circ} \mathrm{C}$ for 24 hours prior to weighing (Arana et al. 2014).

Statistical analyses. The statistical analysis was conducted with the program Statgraphics ${ }^{\circledR}$ Centurion XVI; for the evaluation of the strains, the data are applied to a multivariate analysis of variance (MANOVA) to determine whether the interaction between the strains and the culture media affects growth and/or biomass production. In addition, a correlation analysis was performed between the biomass production and the growth rate in solid medium.

For the biological efficiency and fruit bodies size in the fruiting bioassay, an analysis of variance (ANOVA) was performed; and the significant differences for both analyzes were determined with a Tukey multiple rank test $(P \leq 0.05)$.

Solid spawn production. Wheat seeds were subjected to a process of cleaning, washing and hydration for 24 hours, subsequently boiled for ten minutes. Once drained, $200 \mathrm{~g}$ were weighed and slaked lime $\left[\mathrm{Ca}(\mathrm{OH})_{2}\right](3.5 \mathrm{~g}$ of slaked lime per $\mathrm{kg}$ of seeds) added. The moisture content of the seeds was $77 \%$ and the $\mathrm{pH}$ was 8.5 . The seeds were then placed in flasks (five replicates per treatment) for sterilization in an autoclave at $121^{\circ} \mathrm{C}, 15 \mathrm{lb}$ psi for $1 \mathrm{~h}$ (Guzmán et al. 2013). Once the flasks had cooled, the seeds were inoculated with three $1 \mathrm{~cm}^{2}$ fragments of mycelium from the four strains developed in the two media (DFA and MEAPY); with a factorial design of $4 \times 2 \times 5$ ( 4 strains, 2 culture media, 5 replicates). For the secondary spawn, wheat seeds were subjected to the procedure described above and inoculated with five percent of the primary spawn.

Liquid spawn production. The same procedure described for biomass production in a liquid medium was followed; following 20 days in agitation, the pellets were washed and homogenized in a liquidizer for $10 \mathrm{~s}$ with $100 \mathrm{ml}$ of sterile distilled water (Stamets 2000). Five replicates were conducted per treatment and strain.

Fructification bioassays production. Four different formulations were used as substrates: 1) Quercus sp. sawdust $100 \%$ (QS), 2) Senecio cinerarioides sawdust $100 \%$ (SSC), 3) S. cinerarioides sawdust with maize stubble 50:50 (SSC+MS) and 4) Maize stubble $100 \%$ (MS). The different combinations of substrates were hydrated to $70 \%$ and slaked lime $\left[\mathrm{Ca}(\mathrm{OH})_{2}\right](0.1 \%)$ and gypsum $\left(\mathrm{CaSO}_{4}\right)(0.1 \%)$ added. Two kg of each of the four combinations of substrates were placed in low density plastic bags REYMA ${ }^{\text {M.R. }}$ with a factorial design $4 \times 4 \times 2 \times 5$ (4 strains $\times 4$ substrates $\times 2$ spawn types $\times 5$ replicates). The substrates were sterilized for two hours at $121{ }^{\circ} \mathrm{C}$ and $15 \mathrm{lb}$ psi for $15 \mathrm{~min}$. Once the bags had cooled, they were inoculated with $5 \%$ (based on the substrate moist weight) of solid or liquid spawn. For inoculation with the seeds, an orifice was made in the center of the substrate in which the spawn was placed and for inoculation with liquid, sterile $60 \mathrm{ml}$ syringes were used. The bags were incubated at $18^{\circ} \mathrm{C}$ in darkness, until the mycelium had invaded the substrate. They were then placed in a fructification chamber, under the following conditions: incubation temperature of $18{ }^{\circ} \mathrm{C}$ (Thermo-hygrometer Vaisala ${ }^{\circledR}$ ), relative humidity of 90 $100 \%$ (humidifier Vitallys Plus ${ }^{\circledR}$ ), 70-100 lux of light (luxometer BK Precision ${ }^{\circledR}$ ) and exchange of fresh air for one hour twice a day.

Characterization of harvested fruit bodies. Once the mature fruit bodies were obtained, the biological efficiency (BE) was determined using the equation $\mathrm{BE}=$ fresh weight of harvested fungi / dry weight of the substrate used x 100 (Guzmán et al. 2013). The fruit bodies were characterized macro- and micro-morphologically and compared with those collected in the field. A bromatological analysis of the cultivated mushrooms was conducted; moisture content was calculated based on NOM-116-SSA1-1994, ash content based on NMX-F-607-NORMEX-2013, fat content based on NMX-F-615-NORMEX-2004, protein content (factor 6.25) based on NMX-F-608-NORMEX-2011, raw fiber content based on NMX-F-613-NORMEX-2003 and carbohydrate content by calculation. Three replicates of each treatment were randomly selected. 
Quantification of substrate fiber components. Quantification of fiber components (cellulose-hemicellulose and lignin) for the different treatments was conducted at three stages: prior to inoculation, at the end of incubation and at the end of final mushrooms production, along with a control without spawn for each substrate. Using the detergent method (Goering and Van 1970), the fiber was extracted both in neutral detergent (FND) and in acid detergent (FAD). Lignin was determined with sulfuric acid (72\%), cellulose content was estimated directly from the FDAlignin and hemicellulose content was calculated as FNDFAD (Goering and Van 1970). All analyses were conducted in triplicate and the results presented were based on dry material (\%). Three replicates of each treatment were randomly selected.

\section{RESULTS}

Characterization of wild fruit bodies. Pilei were flatconvex in form, of $2.3(1-2-2.6) \mathrm{cm}$ in size, pale yellow (\#F2F5A9) in color, which as they matured changed into dark yellow (\#8A4B08) and to brown (\#61380B) coloration in the center of the pilei, with a translucent margin, moist-viscous surface with a small umbo in the center. Gills were free of the stipe and pale yellow (\#F2F5A9) in color. Stipes were cylindrical and slightly flattened in form, $2.9(2.4-3.7) \times 0.2(0.1-0.3) \mathrm{cm}$ in size, cartilaginous and with a fibrous surface, the basal part was brown (\#61380B) and as it reached the pilei the color vanished until becoming pale yellow (\#F2F5A9).

Morphological characterization of strains. Morphologically, no differences were found among strains though there were differences among the growth patterns observed in culture media. The mycelium of the four strains in the DFA medium was white (\#FFFFFF) with uniform growth, fimbriate margin, aerial mycelium, cotton-like texture and a flat surface. In contrast, the mycelium of the strains developed in the medium MEA-PY was from light greyish yellow (\#F7F8E0) to dark yellow (\#B18904) and brown (\#61380B), with an irregular shape and prostrate or aerial type growth. Microscopically, the four strains developed hyphae that were branched, septate, smooth and with the presence of clamps. The diameter of the hyphae was similar among strains however differed between culture media; in the DFA medium, the hyphae were slightly thicker $[1.9(1.7-2.7 \mu \mathrm{m})]$ than in the MEA-PY medium [1.7 (1.2-2.5 $\mu \mathrm{m})]$.

Growth rate of strains in solid medium. According to the statistical analysis, the culture medium $(P<0.0001)$ affected growth rate, with the mycelium reaching $9 \mathrm{~cm}$ in diameter in a maximum of 15 days in the DFA medium, for average growth rate of $0.65 \mathrm{~cm}^{-1} \mathrm{day}^{-1}$. This contrasts with the medium MEA-PY, where this value was $0.38 \mathrm{~cm}^{-}$day ${ }^{1}$. In addition to the culture medium, strain $(P \leq 0.0001)$ was also a factor that affected growth rate, as observed in table 1 . The Tukey multiple ranges test shows that strains IE 974 and IE 986 presented the highest growth rate, followed by IE 984 and IE 985 . However, there was no statistically significant interaction $(P \geq 0.0568)$ between strains and culture media.

Biomass production of strains in solid medium. Biomass production in the solid medium presented significant differences in relation to the strain $(P \leq 0.0001)$ and culture me$\operatorname{dium}(P \leq 0.0001)$. There was an interaction $(P \leq 0.0040)$ between these two factors that also affected biomass production. Regarding the Tukey multiple ranges test, biomass production was significantly higher in the medium MEA-PY with strains IE 984, IE 985 and IE 986 nonetheless lower in the DFA medium (table 1). In general, the strains that developed the highest biomass presented lower growth rate $(\mathrm{r}=-0.6134)$.

Biomass production of strains in a liquid medium. The statistical analysis did not reveal significant differences regarding strains $(P \geq 0.2077)$; however, there were differences between culture media $(P \leq 0.0001)$ and no interaction $(P \geq 0.4718)$ between the two factors. The Tukey multiple ranges test revealed that there was superior biomass production in strains IE 984, IE 985 and IE 986 with the medium DF-PY, and lower production in strains IE 974 and IE 984 with the medium ME-PY (table 1). The pellets formed in the liquid medium presented a globose form and fibrous surface. The final $\mathrm{pH}$ of the liquid medium in the four strains changed from 6.1 to 6.4 in the medium DF-PY and from 5.3 to 5.8 in the medium ME-PY.

Inoculation with solid spawn. In all the treatments, the mycelium was dense, white (\#FFFFFF) and presented $100 \%$ invasion of the seeds within 20 days. For the production of secondary spawn, the time of colonization was 15 days with dense mycelium and $100 \%$ invasion of the seeds.

Fructification bioassay. By day 30 of incubation, the strain IE 986 inoculated with liquid spawn had invaded $100 \%$ of the MS substrate, followed by the strain IE 974 within 40 days and the rest of the treatments in 42 days. In the case of strains IE 986 and IE 974 in MS with liquid spawn, the primordia developed in darkness four days after the mycelium invaded the substrate. For the rest of the treatments, fruit bodies formation was induced by removing the bags and leaving the substrate blocks exposed to a relative humidity of 90 to $100 \%$, with continuous light (70-100 lux) for $24 \mathrm{~h}$ per day and exchange of air for one hour twice per day. When the stipes reached $2 \mathrm{~cm}$ in length, a PVC tube of $4.5 \mathrm{~cm}$ in length by $11 \mathrm{~cm}$ in diameter was placed (this is part of a commercial method that allows fruiting bodies to remain firm, since the stipes are usually thin and fragile). They reached their state of maturation in 15 days. The first harvest was made before the pilei margin began to curve 
Table 1. Growth rate and biomass production in four strains of $F$. mexicana (means $\pm \mathrm{SD}$ ).

Velocidad de crecimiento y producción de biomasa de cuatro cepas de F. mexicana (promedio \pm DS).

\begin{tabular}{cccccc}
\hline & \multicolumn{3}{c}{ Solid medium } & \multicolumn{2}{c}{ Liquid medium } \\
\hline Strain & Culture medium & Growth day $\left(\mathrm{cm} \mathrm{day}^{-1}\right)$ & Biomass $(\mathrm{g}$ Petri dish) & Culture medium & Biomass $\left(\mathrm{g} \mathrm{L}^{-1}\right)$ \\
\hline IE974 & MEA-PY & $0.36 \pm 0.00 \mathrm{c}^{*}$ & $0.08 \pm 0.01 \mathrm{c}^{*}$ & ME-PY & $2.3 \pm 0.04 \mathrm{c}^{*}$ \\
& DFA & $0.65 \pm 0.00 \mathrm{a}$ & $0.07 \pm 0.00 \mathrm{c}$ & DF-PY & $6.9 \pm 0.21 \mathrm{ab}$ \\
IE 984 & MEA-PY & $0.26 \pm 0.02 \mathrm{~d}$ & $0.18 \pm 0.03 \mathrm{a}$ & ME-PY & $2 \pm 0.22 \mathrm{c}$ \\
& DFA & $0.57 \pm 0.00 \mathrm{~b}$ & $0.10 \pm 0.00 \mathrm{c}$ & DF-PY & $8.7 \pm 0.25 \mathrm{a}$ \\
IE 985 & MEA-PY & $0.29 \pm 0 \mathrm{~d}$ & $0.16 \pm 0.02 \mathrm{ab}$ & ME-PY & $4.7 \pm 0.28 \mathrm{abc}$ \\
& DFA & $0.58 \pm 0.03 \mathrm{~b}$ & $0.10 \pm 0.00 \mathrm{c}$ & DF-PY & $8.5 \pm 0.27 \mathrm{a}$ \\
IE 986 & MEA-PY & $0.38 \pm 0.01 \mathrm{c}$ & $0.18 \pm 0.01 \mathrm{a}$ & ME-PY & $3.1 \pm 0.18 \mathrm{bc}$ \\
& DFA & $0.65 \pm 0 \mathrm{a}$ & $0.11 \pm 0.04 \mathrm{bc}$ & DF-PY & $7.7 \pm 0.05 \mathrm{a}$ \\
\hline
\end{tabular}

DFA: Dog Food Agar, MEA-PY: Malt Extract Agar-Peptone and Yeast, DF-PY: Dog Food-Peptone and Yeast, ME-PY: Malt Extract-Peptone and Yeast. *Different letters in the same column indicate significant differences (Tukey, $P \leq 0.05$ ).

upwards, with average production of a $100 \mathrm{~g}$ per bag. The culture cycles stopped at the end of the third harvest, with a period of 6 days between harvests for induction of the fruit bodies and 15 days for their maturation.

Strains IE 974, IE 984 and IE 985 with liquid spawn in SSC+MS, and IE 986 in SSC+MS with solid spawn began to form small mushrooms at 13 days after the process of induction; however, these did not mature and therefore their BE was not reported. The rest of the treatments, mainly those with $S$. cinerarioides and Quercus sp. sawdust with solid and liquid spawn, presented slow mycelial growth and did not invade completely, which allowed the substrates to become contaminated with Trichoderma sp., and those that were invaded did not form mushrooms (IE 984 and IE 986).

Strains presented differences in $\mathrm{BE}(P \leq 0.0001)$; strains IE 974 and IE 986 with MS inoculated with liquid medium presented the highest $\mathrm{BE}$ compared to the rest of the strains and treatments, with up to 31.9 and $34.5 \%$, respectively. Strains IE 986 and IE 985 fructified in MS with solid and liquid spawn. As shown in table 2, in both cases the liquid spawn is more efficient than the solid spawn, both in terms of fruit bodies production and times of colonization of the substrate. IE 986 was the only strain to fructify in two different substrates (MS and SSC+MS), of which the latter substrate presented the lowest BE (5.8\%). In total, the culture cycle for the strain IE 986 in MS with liquid spawn was 91 days, while for the strain IE 974 this was 101 days, beginning from incubation of the substrate until acquisition of a third harvest with mature mushrooms. With solid spawn, the culture cycle was 117 days. The rest of the treatments had a cycle culture of 103 days.

Characterization of cultivated fruit bodies. Morphologically, the cultivated mushrooms were very similar to their wild counterparts (figure 1). Pilei reached an average size of $2(1.3-3.7) \mathrm{cm}$, were flat-convex in form and pale yellow in color (\#F2F5A9, \#F7D358). As they matured, the center of the pilei changed from dark yellow (\#8A4B08) to brown (\#61380B) coloration in its center, with a translucent margin, moist-viscous surface with a small umbo in the center. Gills were free of the stipe, joined and pale yellow in color (\#F2F5A9, \#F5DA81). Stipes were cylindrical and slightly flattened in form, 7.2 (3-10) x $0.2(0.1-0.5)$ $\mathrm{cm}$ in size, cartilaginous and with a fibrous surface, the basal part was brown (\#61380B) and as it reached the pilei, the color vanished until reaching a pale yellow (\#F2F5A9). Regarding size, the cultivated mushrooms had larger pilei and stipes than those presented by their wild counterparts. The pilei diameter presented statistical differences among treatments and strains (twenty fruit bodies were measured per treatment bag) (table 2).

In terms of the bromatological analysis of the cultivated mushrooms, which was conducted only with the mushrooms of the strain IE 986 harvested in MS, the following results were obtained based on $6.42 \%$ of dry material: moisture content $93.58 \%$, ashes $12.72 \%$, fats $1.64 \%$, protein (factor: 6.25 ) $17.68 \%$, raw fiber $52.51 \%$ and carbohydrates $9.03 \%$.

Quantification of the substrate fiber components. To identify the component(s) of the fiber that are capable of degradation by $F$. mexicana, a fiber analysis of the substrates that were completely colonized by mycelium, and those from which fruit bodies were obtained, was conducted. In the different treatments, in both periods of quantification (substrates colonized by mycelium and spent-ground) the percentages of hemicellulose decreased contrasted with the control; however, in the final stage after the third harvest, this component decreased by more than half, while 
Table 2. Size of wild and cultivated mushrooms and biological efficiency of $F$. mexicana (means $\pm \mathrm{SD}$ ).

Tamaño de los hongos silvestres y cultivados y eficiencia biológica de F. mexicana (promedio \pm DS).

\begin{tabular}{cccccc}
\hline \multirow{2}{*}{ Treatment } & \multirow{2}{*}{$\begin{array}{c}\text { Type of } \\
\text { spawn }\end{array}$} & Diameter $(\mathrm{cm})$ & Length $(\mathrm{cm})$ & Stipe & $\begin{array}{c}\text { Biological } \\
\text { Efficiency }\end{array}$ \\
\cline { 3 - 5 } Wild fruit bodies & & $2.3(1.6-2.6)$ & $2.9(2.4-3.7)$ & Diameter $(\mathrm{cm})$ & $0.2(0.1-0.3)$ \\
IE 974/MS & $\mathrm{L}$ & $2.15(1.5-3) \pm 0.60 \mathrm{ab}^{*}$ & $7.52(5.5-9) \pm 1.38 \mathrm{ab} *$ & $0.24(0.2-0.4) \pm 0.08 \mathrm{ab} *$ & $31.9 \pm 2.91 \mathrm{a}^{*}$ \\
IE 986/MS & $\mathrm{L}$ & $1.86(1.5-2.7) \pm 0.40 \mathrm{~b}$ & $7.82(6-10) \pm 1.23 \mathrm{a}$ & $0.24(0.2-0.4) \pm 0.08 \mathrm{ab}$ & $34.5 \pm 4.09 \mathrm{a}$ \\
IE 986/MS & $\mathrm{S}$ & $1.98(1.3-2.5) \pm 0.41 \mathrm{ab}$ & $6.86(3-9) \pm 2.31 \mathrm{abc}$ & $0.23(0.15-0.25) \pm 0.05 \mathrm{ab}$ & $14.8 \pm 1.96 \mathrm{~b}$ \\
IE 986/SSC+MS & $\mathrm{L}$ & $2.15(1.5-3) \pm 0.45 \mathrm{ab}$ & $6.02(4.3-7) \pm 0.79 \mathrm{abc}$ & $0.17(0.1-0.25) \pm 0.05 \mathrm{~b}$ & $5.84 \pm 1.00 \mathrm{~d}$ \\
IE 985/MS & $\mathrm{L}$ & $1.91(1.5-2.2) \pm 0.20 \mathrm{~b}$ & $5.99(4.2-7.2) \pm 0.84 \mathrm{bc}$ & $0.22(0.2-0.3) \pm 0.03 \mathrm{~b}$ & $8.7 \pm 0.50 \mathrm{~cd}$ \\
IE 984/MS & $\mathrm{L}$ & $2.55(1.7-3.7) \pm 0.65 \mathrm{a}$ & $5.68(4-7) \pm 0.96 \mathrm{c}$ & $0.34(0.15-0.5) \pm 0.16 \mathrm{a}$ & $10.8 \pm 0.76 \mathrm{bc}$ \\
IE 985/MS & $\mathrm{S}$ & $1.76(1.5-2.1) \pm 0.22 \mathrm{~b}$ & $5.65(4.2-7) \pm 1.07 \mathrm{c}$ & $0.18(0.1-0.25) \pm 0.04 \mathrm{~b}$ & $7.18 \pm 0.72 \mathrm{~cd}$ \\
\hline
\end{tabular}

MS: Maize stubble, SSC+MS: S. cinerarioides sawdust and maize stubble, L: liquid spawn, S: solid spawn. *Different letters in the same column indicate significant differences (Tukey, $P \leq 0.05$ ).

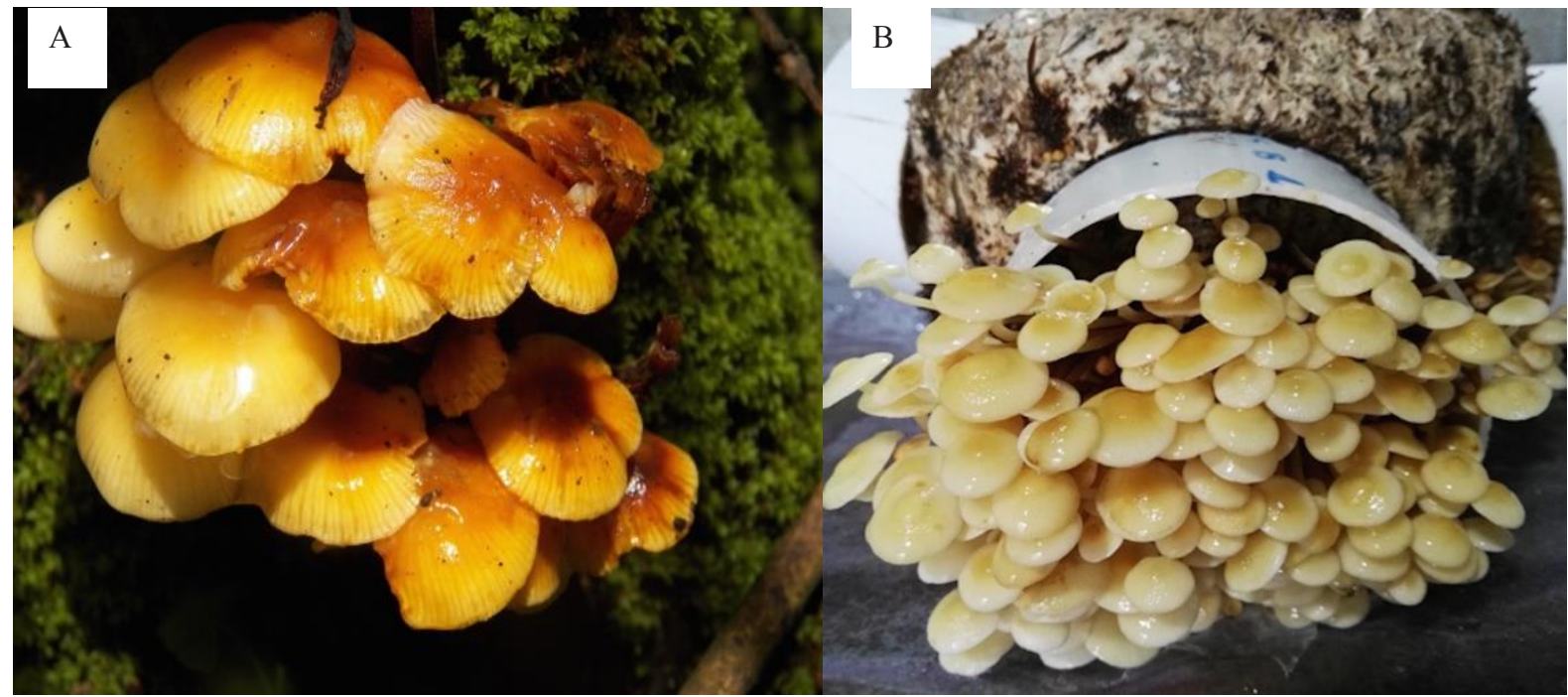

Figure 1. Flammulina mexicana. A) Wild mushrooms growing on S. cinerarioides, B) cultivated mushrooms on maize stubble (MS). Flammulina mexicana. A) hongos silvestres creciendo sobre $S$. cinerarioides, B) Cultivo sobre rastrojo de maíz (RM).

the quantity of cellulose increased slightly and that of lignin doubled (table 3 ).

This trend was clearly observed in the MS substrate, which presented the highest quantity of hemicellulose and lowest quantity of cellulose and lignin among the four different substrates. In the strain IE 986 with MS, which presented the highest $\mathrm{BE}$, hemicellulose decreased from 28.23 to $12.02 \%$, cellulose increased slightly from 30.83 to $35.86 \%$ and lignin increased from 5.08 to $12.86 \%$. Therefore, it is inferred that $F$. mexicana could be a species of brown-rot fungus.

For the rest of the treatments, data pertaining to the consumption of hemicellulose were obtained after the in- cubation period, when substrates were completely invaded by the mycelium (table 2). For example, for SSC+MS (IE 984), hemicellulose decreased from 27.21 to $22.34 \%$, cellulose remained the same as with the strain IE 984 or decreased from 32.39 to $28.73 \%$ in IE 986 and lignin stayed the same or decreased from 13.68 to 7.44 in IE 985 . In SSC, hemicellulose decreased from 23.79 to $18.12 \%$ in the strain IE 986, as did the cellulose from 32.48 to $30.89 \%$ in IE 984. Concerning lignin, statistically there were no changes. In the substrate QS, with the strain IE 984, hemicellulose and cellulose decreased from 21.42 to $17.49 \%$ and from 42.24 to $38.37 \%$, respectively, and there were no differences in the lignin contrasted with the control. 
Table 3. Fiber analysis in colonized substrates with fruit bodies production (means $\pm \mathrm{SD}$ ).

Análisis de fibra en sustratos colonizados y con producción de cuerpos fructíferos (promedio \pm DS).

\begin{tabular}{|c|c|c|c|c|c|c|c|c|}
\hline \multirow[b]{2}{*}{ Strain } & \multirow[b]{2}{*}{ Substrate } & \multirow{2}{*}{$\begin{array}{l}\text { Type of - } \\
\text { spawn }\end{array}$} & \multicolumn{3}{|c|}{ Invaded substrate } & \multicolumn{3}{|c|}{ Harvested substrate } \\
\hline & & & $\begin{array}{c}\text { Hemicellulose } \\
(\%)\end{array}$ & $\begin{array}{c}\text { Cellulose } \\
(\%)\end{array}$ & $\begin{array}{l}\text { Lignin } \\
(\%)\end{array}$ & $\begin{array}{c}\text { Hemicellulose } \\
(\%)\end{array}$ & $\begin{array}{l}\text { Cellulose } \\
(\%)\end{array}$ & $\begin{array}{l}\text { Lignin } \\
(\%)\end{array}$ \\
\hline Control & MS & - & $28.23 \pm 0.01 \mathrm{a}^{*}$ & $30.83 \pm 0.31 \mathrm{fgh}$ & $5.08 \pm 0.89 j$ & $28.23 \pm 0.01 \mathrm{a}$ & $30.83 \pm 0.31 \mathrm{ef}$ & $5.08 \pm 0.89 \mathrm{f}$ \\
\hline Control & $\mathrm{MS}+\mathrm{SSS}$ & - & $27.21 \pm 0.13 \mathrm{ab}$ & $32.39 \pm 0.10 \mathrm{ef}$ & $13.68 \pm 0.19 \mathrm{de}$ & $27.21 \pm 0.13 b$ & $32.39 \pm 0.10 \mathrm{de}$ & $13.68 \pm 0.19 \mathrm{~d}$ \\
\hline Control & $\mathrm{SSC}$ & - & $23.79 \pm 0.29 \mathrm{~cd}$ & $32.48 \pm 0.87 \mathrm{ef}$ & $18.1 \pm 0.30 \mathrm{c}$ & $23.79 \pm 0.29 \mathrm{c}$ & $32.48 \pm 0.87 \mathrm{de}$ & $18.1 \pm 0.31 b$ \\
\hline Control & QS & - & $21.42 \pm 0.37 \mathrm{efg}$ & $42.24 \pm 0.37 \mathrm{a}$ & $23.13 \pm 0.67 \mathrm{a}$ & $21.42 \pm 0.37 \mathrm{~d}$ & $42.24 \pm 0.37 \mathrm{a}$ & $23.13 \pm 0.67 \mathrm{a}$ \\
\hline IE 974 & MS & $\mathrm{L}$ & $13.66 \pm 0.54 \mathrm{j}$ & $35.52 \pm 0.92 \mathrm{~cd}$ & $9.13 \pm 0.39 \mathrm{~h}$ & $10.95 \pm 0.26 \mathrm{~g}$ & $37.32 \pm 0.26 b c$ & $12.79 \pm 0.26 \mathrm{~d}$ \\
\hline IE 984 & MS & L & $24.33 \pm 0.63 \mathrm{~cd}$ & $25.50 \pm 0.81 \mathrm{i}$ & $7.42 \pm 0.17 \mathrm{i}$ & $13.12 \pm 0.00 \mathrm{e}$ & $33.6 \pm 1.35 \mathrm{~d}$ & $10.06 \pm 0.56 \mathrm{e}$ \\
\hline IE 985 & MS & S & $21.65 \pm 0.45 \mathrm{efg}$ & $19.97 \pm 0.50 \mathrm{j}$ & $9.40 \pm 0.23 \mathrm{gh}$ & $10.26 \pm 0.04 \mathrm{gh}$ & $24.83 \pm 0.68 \mathrm{~g}$ & $10.84 \pm 0.36 \mathrm{e}$ \\
\hline IE 985 & MS & $\mathrm{L}$ & $25.16 \pm 0.84 b c$ & $30.01 \pm 0.76 \mathrm{gh}$ & $6.57 \pm 0.13 i$ & $12.42 \pm 0.12 \mathrm{ef}$ & $30.42 \pm 0.35 f$ & $10.57 \pm 0.18 \mathrm{e}$ \\
\hline IE 986 & MS & $\mathrm{S}$ & $13.92 \pm 0.41 \mathrm{i}$ & $34.67 \pm 0.41 \mathrm{de}$ & $10.45 \pm 0.24 \mathrm{~g}$ & $12.10 \pm 0.47 \mathrm{f}$ & $30.07 \pm 0.15 f$ & $10.58 \pm 0.69 \mathrm{e}$ \\
\hline IE 986 & MS & $\mathrm{L}$ & $25.17 \pm 0.90 \mathrm{bc}$ & $25.65 \pm 0.83 \mathrm{i}$ & $7.63 \pm 0.17 i$ & $12.02 \pm 0.27 \mathrm{f}$ & $35.86 \pm 0.75 \mathrm{c}$ & $12.86 \pm 0.42 \mathrm{~d}$ \\
\hline IE 986 & $\mathrm{SSC}+\mathrm{MS}$ & $\mathrm{L}$ & $23.51 \pm 0.72 \mathrm{cde}$ & $28.73 \pm 0.79 h$ & $13.06 \pm 0.28 \mathrm{ef}$ & $10.19 \pm 0.03 \mathrm{~h}$ & $37.94 \pm 0.25 b$ & $15.45 \pm 0.11 \mathrm{c}$ \\
\hline
\end{tabular}

QS: Quercus sp. sawdust, SSC: S. cinerarioides sawdust; MS: maize stubble, SSC+MS: S. cinerarioides sawdust and maize stubble, L: liquid spawn, $\mathrm{S}$ : solid spawn. *Different letters in the same column indicate significant differences (Tukey, $P \leq 0.05$ ).

\section{DISCUSSION}

For the experimental cultivation of $F$. mexicana from native strains, the DFA culture medium, considered a nonconventional source of carbon is the most suitable medium for in vitro culture. Chegwin and Nieto (2013) report that some non-conventional carbon sources generate good biomass production, with more important growth rate and higher production of metabolites, and can also be used in the culture of other species of fungi, thus decreasing process cost.

Using a solid medium, F. mexicana presented maximum biomass production in the medium MEA-PY at $0.18 \mathrm{~g}$ Petri dish. Using a liquid medium, this was presented at $8.7 \mathrm{~g} \mathrm{~L}^{-1}$ in the DF-PY medium. These results are similar to those of $F$. velutipes, where biomass production of 4.16-4.82 $\mathrm{g} \mathrm{L}^{-1}$ was reported after 15 days at $25^{\circ} \mathrm{C}$ (Kim et al. 2002) and $5.5 \mathrm{~g} \mathrm{~L}^{-1}$ by day 10 (Kozhemyakina et al. 2010). Biomass production in a liquid medium depends on species, intensity of agitation and the nutrients in the culture medium. It has been reported that biomass production increases 1.5 to 2 times in liquid media relative to production in solid media (Kozhemyakina et al. 2010), as was demonstrated in this study with $F$. mexicana. Because superior quantity of biomass of higher quality is produced in a shorter time in a liquid medium (Frieal and McLoughlin 2000 ) it can be used as spawn.

Spawn type (solid or liquid) affected the time of substrate colonization; the liquid spawn developed dense mycelium and was the first to invade, compared to the substrates inoculated with seed. Mushrooms production was more rapid in substrates with liquid spawn. These trends agree with that reported for other species, such as Agaricus blazei Murill (Lin and Yang 2006) and Pleurotus ostreatus (Jacq. ex. fr) Kummer. (Silveira et al. 2008). Due to the fact that the liquid medium can be inoculated directly into the substrate, incubation time is reduced and there is better density of mycelium, more uniform distribution in the substrates and fewer problems of contamination (Frieal and McLoughlin 2000).

The moisture content of the substrates and ambient temperature are important factors for mycelium growth. All substrates were adjusted to $70 \%$ of moisture content; however, this percentage could have affected the sawdustbased substrates, slowing the growth rate and preventing the mycelium from completely invading the substrate, leading to problems of contamination. Rapid invasion of substrates would avoid contamination by other microorganisms. For $F$. velutipes, the optimum moisture content is $60-65 \%$ (Sharma et al. 2010), therefore, it is suggested that the moisture content for sawdust-based substrates should be less than $70 \%$.

For fruit bodies production, the best strain was IE 986 in MS with liquid spawn. This strain invaded in a maximum of 30 days, a period similar to that of $F$. velutipes, which invades in approximately 25 days (Royse 1996). Fruit bodies formation began at day 34 of incubation in darkness at a temperature of 16 to $18{ }^{\circ} \mathrm{C}$. To stimulate formation, it is important to consider factors such as light and moisture content of both the substrate and the environment. The temperature conditions under which $F$. mexicana fructified were very different to those for $F$. velutipes, which had to 
be subjected to different temperature changes for a period of 10 to 14 days (Royse 1996). However, for both species, the primordia are induced in conditions of darkness, which explains why there were blocks that did not fructify in the presence of light or in some cases even failed to mature.

Once the fruit bodies had developed, exchange of fresh air was carried out twice a day with alternating $12 \mathrm{~h}$ periods of light and darkness. Light, exchange of fresh air and moisture content are all essential elements for fruit bodies maturation (Sakamoto et al. 2004).

The aerial growth of the mycelium that $F$. mexicana presented in culture at strain level suggests that it is a species that must be subjected to conditions of sufficient oxygen as with $F$. velutipes. This condition is reflected in the size of the fruit bodies, which presented pilei with smaller diameters and longer stipes than those found in wild specimens of this species. The pilei of the wild mushrooms measure $2.2 \times 2.3 \mathrm{~cm}$ and the stipes $2.9 \times 0.2 \mathrm{~cm}$, while those obtained in culture present pilei of $1.9(1-5-2.7) \times$ $1.7(1-2.9) \mathrm{cm}$ and stipes of $7.2(3-10) \times 0.2(0.1-0.4) \mathrm{cm}$.

These changes are affected by both the exchange of fresh air and quantity of light. In a commercial cultivation of $F$. velutipes, the concentrations of $\mathrm{CO}_{2}$ and intensity of light are altered in order to modify the size of the pilei and stipe. When $\mathrm{CO}_{2}$ concentrations increase, pilei diameters decrease and the stipes elongate to $14-18 \mathrm{~cm}$ (Sharma et al. 2010). In conditions of darkness, the stipes are elongated and thin and present small pilei (pinhead fruit body) that are whiter in color than those that formed in the presence of light (Sakamoto et al. 2004).

In terms of the BE, strains IE 986 and IE 974 had a percentage in three harvests that exceeded that of the other two strains (table 2); however, when compared with the BE of F. velutipes, it was very low. For F. velutipes, Harith et al. 2014 report BE values between 48-138\% in supplemented substrates and up to $150 \%$ in fiber of palm and rice.

Despite the low BE found compared to that of $F$. velutipes, it is important to note that this study represents the first experimental cultivation conducted with $F$. mexicana and that the substrates utilized by this study were not supplemented. The supplementation substrates will have a better biological efficiency (Harith et al. 2014). The mycelial growth and the fruit bodies production in the experimental cultivation depend of the genetic characteristics of each species, strains, substrates and spawn types used (Philippoussis et al. 2001). The liquid spawn is more efficient in the substrate colonization; strains IE 986 and IE 974 showed higher production of biomass and growth rate in vitro culture, hence those with a shorter culture cycle are more capable of producing fruit bodies.

Regarding the nature of the substrates, the decrease in hemicellulose and cellulose in the four different substrates prior to formation of fruit bodies and after the third harvest indicated that $F$. mexicana has the capacity to selectively degrade cellulosic and hemicellulosic components. In this way, the substrates MS and MS+SSC that presented a hig- her percentage of hemicellulose and lignin also had the highest rate of mycelial growth and mushrooms production. The capacity for degradation is therefore influenced by the nature of the substrate, environmental and genetic factors among species or even among strains of the same species, enzymes and the quantity and resistance of the cellulose, hemicellulose and lignin (Economou et al. 2017).

The substrates used for the cultivation of mushrooms are generally derived from agricultural, agro-industrial or forestry wastes, which are found with varying availability in different regions (Salmones and Mata 2012). The success of the $F$. mexicana culture in maize stubble is highly important, considering that this substrate is one of the most commonly available agricultural wastes in the central region of Mexico. This also contributes to the reduction of costs and avoids the use of its natural substrate (S. cinerarioides) in the context of a commercial cultivation process.

In terms of the nutrient content of the cultivated F. mexicana mushrooms (ashes $12.72 \%$, fats $1.64 \%$, protein $17.68 \%$, raw fiber $52.51 \%$ and carbohydrates $9.03 \%$ ), values are within the ranges reported for other species (Sharma et al. 2010) with the exception of fiber content. The cultivated mushrooms of the $F$. mexicana strain IE 986 in MS presented high percentage of fiber and low percentage of carbohydrates; this trend supports that reported for Ganoderma tsugae Murrill, which presents high percentage of fiber (73.4) and, as the mushrooms mature, the quantity of fiber increases and the contents of other components are reduced (Tseng et al. 2005). These results allow $F$. mexicana to be considered a good source of fiber. This fiber is mostly composed of chitin (25\%), hemicelluloses, mannans and $\beta$-glucans (4-13\%), which are all components of the cell wall (Manzi and Pizzoferrato 2000). These components confer anti-allergen activities and participate in modulation of the immune system, prevention of the promotion and progression of certain types of cancer and reduction of levels of cholesterol in the blood, among other functional properties (Manzi and Pizzoferrato 2000).

It is possible to obtain fructifications at an experimental culture level of F. mexicana from wild strains. Mycelial growth and production of fruiting bodies in the different substrates depend on the strain and the type of spawn, being more efficient by the time of colonization the liquid spawn. Strains IE 986 and IE 974 present higher production of biomass and growth rate in in vitro culture, hence, for the production of fruiting bodies are more appropriate those that have a shorter culture cycle (91 days) and better biological efficiency with maize stubble as a substrate. The production of fruiting bodies occurs at a temperature of 16$18^{\circ} \mathrm{C}$, light intensity of 70-100 lux, exchange of air for one hour twice per day and a relative humidity of $90-100 \%$. Cultivated fruit bodies are high in fiber $(52.51 \%)$ and low in carbohydrates $(9.03 \%)$.

In this way, cultivation is an excellent alternative for the conservation of $F$. mexicana, which by developing only on S. cinerarioides, at elevations above 2700 meters and being 
intolerant to heat, as well as being considered a species endemic to the high mountains, is currently restricted to small isolated populations or "islands" (Redhead et al. 2000).

These types of studies, focused on the experimental cultivation of wild edible mushrooms, form the basis for continued research that helps to identify the strains, culture media, environmental conditions and substrates that can be used and/or modified to optimize the culture process and obtain superior yields. Safeguarding the germplasm and the culture of new native species represents a viable alternative for their ex situ conservation (Salmones and Mata 2012, Alvarado-Castillo et al. 2015).

\section{CONCLUSIONS}

It is possible to obtain fructification at an experimental culture level of $F$. mexicana from wild strains. There are differences in the biological efficiency related to the genetic variability of the four strains of $F$. mexicana. Mycelial growth and the production of fruiting bodies in the different substrates depending on the strain and the type of spawn are more efficient by the time of colonization in the liquid spawn. Strains IE 986 and IE 974 present higher production of biomass and growth rate in in vitro culture, hence, for the production of fruiting bodies are those that have a shorter culture cycle (91 days) and better biological efficiency with maize stubble as a substrate. The production of fruiting bodies occurs at a temperature of $16-18{ }^{\circ} \mathrm{C}$, light intensity of 70-100 lux, exchange of air for one hour twice per day and a relative humidity of 90-100 \%. Cultivated fruit bodies are high in fiber and low in carbohydrates.

Strains could be used for research focused on breeding programs for strains, to obtain higher yields and desirable characteristics in the commercial sector; allowing the use and conservation of germplasm of native species.

The cultivation of $F$. mexicana could represent a viable alternative in the diversification of the cultivated species and the use of the natural resources of each region, including agricultural, forestry or agroindustrial wastes and the specific environmental conditions required by each species. Such is the particular case of corn stubble, one of the most available and low-cost waste in central Mexico.

\section{ACKNOWLEDGMENTS}

The authors would like to thank the Faculty of Sciences, Autonomous Mexico State University for the logistic support. This study was carried out as part of the investigation projects "Ethnopharmacologic, nutritional and nutriceutic advances of priority vegetal and fungal resources for Water Sanctuary Presa Corral de Piedra Communities", financed by SEP-PRODEP, UAEM-CA-273- 2018, and "Diversity, isolation and strains propagation of edible and medicinal mushrooms of the State of Mexico" UAEM 4985/2020CIB. The authors also thank Ph.D. Julieta Ger- trudis Estrada Flores of the Institute of Agricultural and Rural Sciences for her support in the technique of quantification of substrate fiber components. DNA sequencing was funded by the MEXBOL network CONACYT grant 280896.

\section{REFERENCES}

Alvarado-Castillo G, G Mata, G Benítez-Badillo. 2015. Importancia de la domesticación en la conservación de los hongos silvestres comestibles en México. Bosque 36(2): 151-161. DOI: $10.4067 / \mathrm{S} 0717-92002015000200001$

Arana-Gabriel Y, C Burrola-Aguilar, R Garibay-Orijel, S FrancoMaass. 2014. Obtención de cepas y producción de inóculo de cinco especies de hongos silvestres comestibles de alta montaña en el centro de México. Revista Chapingo Serie Ciencias Forestales y del Ambiente 20: 213-226. DOI: 10.5154/r.rchscfa.2014.04.017.

Chegwin AC, RIJ Nieto. 2013. Influencia del medio de cultivo en la producción de metabolitos secundarios del hongo comestible Pleurotus ostreatus cultivado por fermentación en estado líquido empleando harinas de cereales como fuente de carbono. Revista Mexicana de Micología 37: 1-9.

Cruz-Ulloa BS. 1995. Micorrizas un caso de simbiosis entre plantas y hongos. México DF, México. UNAM. 102 p.

De León R, D Lau, R Vallejo, C Klee. 2012. Requerimientos fisiológicos que inciden en el crecimiento micelial y la degradación del sustrato por Agrocybe aegerita. In Sánchez VJ, G Mata eds. Hongos Comestibles y Medicinales en Iberoamérica, investigación y desarrollo en un entorno multicultural. México DF, México. INECOL-ECOSUR. p. 241-254.

Delgado FA, RM Vilegas, BJ Cifuentes. 2005. Glosario ilustrado de los caracteres macroscópicos en Basidiomycetes con himenio laminar. México DF, México. Las Prensas de Ciencias. $84 \mathrm{p}$.

Economou NC, AP Diamantopoulou, NA Philippoussis. 2017. Valorization of spent oyster mushroom substrate and laccase recovery through successive solid state cultivation of Pleurotus, Ganoderma and Lentinula strains. Applied Microbiology and Biotechnoly 101: 5213-5222. DOI: $\underline{10.1007 / \mathrm{s} 00253-017-8251-3 .}$

Franco MS, C Burrola-Aguilar, Y Arana-Gabriel. 2012. Hongos comestibles silvestres: Un recurso forestal no maderable del Nevado de Toluca. México DF, México. EON. 342 p.

Frieal MT, AJ McLoughlin. 2000. Production of a liquid inoculum/spawn of Agaricus bisporus. Biotechnology Letters 22: 351-354. DOI: 10.1023/A:1005616516646.

Garibay-Orijel R, F Ruan-Soto, E Estrada-Martínez. 2010. El conocimiento micológico tradicional, motor para el aprovechamiento de los hongos comestibles y medicinales. In Martínez-Carrera D, N Curvetto, M Sobal, P Morales, VM Mora eds. Hacia un desarrollo sostenible del sistema de producción-consumo de los hongos comestibles y medicinales en Latinoamérica: Avances y perspectivas en el siglo XXI. Puebla, México. Red Latinoamericana de Hongos Comestibles y Medicinales-COLPOS-UNS-CONACYTUAEM-UPAEP-IMINAP. p. 243-270.

Garibay-Orijel R, F Ruan-Soto. 2014. Listado de los hongos silvestres consumidos como alimento tradicional en México. In Moreno-Fuentes A, R Garibay-Orijel eds. La etnomico- 
logía en México, estado del arte. México DF, México. CONACYT, UAEH, UNAM. p. 91-109.

Goering HK, SPJ Van. 1970. Forage Fiber Analysis (Apparatus, Reagents, Procedures and Some Applications). Agric Hand-book No. 379, Washington DC. ARS-USDA. 20 p. https://catalyst.library.jhu.edu/catalog/bib_4172452

Guzmán G, G Mata, D Salmones, C Soto-Velazco, L GuzmánDávalos. 2013. El cultivo de los hongos comestibles. Con especial atención a especies tropicales y subtropicales en esquilmos y residuos agro-industriales. México DF, México. IPN. 245 p.

HTML Color Codes. 2017. Identifier used to represent a color on the web. Available in http://html-color-codes.info.

Harith N, N Abdullah, V Sabaratnam. 2014. Cultivation of Flammulina velutipes mushroom using various agro-residues as a fruiting substrate. Pesquisa Agropecuária Brasileira 49: 181-188. DOI: 10.1590/S0100-204X2014000300004.

Huerta G, D Martínez-Carrera, JE Sánchez, H Leal-Lara. 2009. Grupos de interesterilidad y productividad de cepas de Pleurotus de regiones tropicales y subtropicales de México. Revista Mexicana de Micología 30: 31-42. http://www. redalyc.org/articulo.oa? id=88316009004.

Kim JM, KS Ra, DO Noh, HJ Suh. 2002. Optimization of submerged culture conditions for the production of angiotensin converting enzyme inhibitor from Flammulina velutipes. Journal of Industrial Microbiology and Biotechnology 29: 292-295. DOI: 10.1038/sj.jim.7000306.

Kozhemyakina NV, EP Ananyeva, SV Gurina, VA Galynkin. 2010. Conditions of cultivation, composition, and biological activity of mycelium of Flammulina velutipes (Fr.) P. Karst. Applied Biochemistry and Microbiology 46: 536539. DOI: 10.1134/S0003683810050121.

León-Aveldaño, H, R Martínez-García, P, Caballero-Gutiérrez, D. Martínez-Carrera. 2013. Caracterización de dos cepas de Pleurotus djamor nativas de Oaxaca, México. Revista Mexicana de Ciencias Agrícolas 6: 1285-1291.

Lin JH, SS Yang. 2006. Mycelium and polysaccharide production of Agaricus blazei Murill by submerged fermentation. Journal of Microbiology, Immunology and Infection 39(2): 98-108.

Manzi P, L Pizzoferrato. 2000. Beta-glucans in edible mushrooms. Food Chemistry 68: 315-318. DOI: $\underline{10.1016 /}$ S0308-8146(99)00197-1.

Morales P, M Sobal, M Bonilla et al. 2010. Los hongos comestibles silvestres en México: recursos genéticos, biotecnología, y desarrollo del sistema de producción-consumo. In Martínez-Carrera D, N Curvetto, M Sobal, P Morales, VM Mora eds. Hacia un desarrollo sostenible del sistema de producción-consumo de los hongos comestibles y medici- nales en Latinoamérica: Avances y perspectivas en el siglo XXI. Puebla, México. Red Latinoamericana de Hongos Comestibles y Medicinales-COLPOS-UNS-CONACYTUAEM-UPAEP-IMINAP. p. 91-108.

Philippoussis A, G Zervakis, P Diamantopoulou. 2001. Bioconversion of agricultural lignocellulosic wastes through the cultivation of the edible mushrooms Agrocybe aegerita, Volvariella volvacea and Pleurotus spp. World Journal of Microbiology and Biotechnology 17: 191-200. DOI: 10.1023/A:1016685530312.

Redhead AS, A Estrada-Torres, HR Petersen. 2000. Flammulina mexicana, a new mexican species. Mycologia 92: 10091018. DOI: $10.2307 / 3761595$.

Royse DJ. 1996. Specialty mushrooms. In Janick J ed. Progress in new crops. Arlington. USA. ASHS Press. p. 464-475.

Royse DJ, J Baars, Q Tan. 2017. Current overview of mushroom production in the world. In Cunha Zied D, A Pardo-Giménez eds. Edible and Medicinal Mushroom: Technology and Applications. Oxford. Wiley Blackwell. p. 5-13. DOI: 10.1002/9781119149446.ch2

Salmones D, G Mata. 2012. Cepario de hongos en México. In Sánchez VJ, G. Mata eds. Hongos Comestibles y Medicinales en Iberoamérica, investigación y desarrollo en un entorno multicultural. México DF, México. INECOL-ECOSUR. p. 69-77.

Sakamoto Y, Y Tamai, T Yajima. 2004. Influence of light on the morphological changes that take place during the development of the Flammulina velutipes fruit body. Mycoscience 45: 333-339. DOI: 10.1007/s10267-004-0195-7.

Savoie J-M, G Mata. 2016. Growing Agaricus bisporus as a contribution to sustainable agricultural development. In Petre M ed. Mushroom Biotechnology. Developments and applications. London, UK. Academic Press. p. 69-91. DOI: 10.1016/B978-0-12-802794-3.00005-9

Sharma VP, S Kumar, RP Tewari. 2010. Flammulina velutipes, the culinary medicinal winter mushroom. New Delhi: Technical Bulletin. Directorate of Mushroom Research. https:// www.semanticscholar.org/paper/Flammulina-velutipes\%2C-The-Culinary-Medicinal-Sharma-Kumar/618208731 46f6d0281132097c4581ee2672d469c

Silveira LML, AS Furlan, JL Ninow. 2008. Development of an alternative technology for the oyster mushroom production using liquid inoculum. Ciência e Tecnologia de Alimentos 28: 858-862. DOI: 10.1590/S0101-20612008000400014.

Stamets P. 2000. Growing Gourmet and Medicinal Mushrooms. New York, USA. Ten Speed Press.

Tseng YH, YL Lee, RC Li, JL Mau. 2005. Non-volatile flavor components of Ganoderma tsugae. Food Chemistry 90: 409-415. DOI: 10.1016/j.foodchem.2004.03.054. 